\title{
THE THERMAL REGIME AND SPECIES COMPOSITION OF FISH AND INVERTEBRATES IN KELLY WARM SPRING, GRAND TETON NATIONAL PARK, WYOMING
}

\author{
David D. Harper1,2 and Aïda M. Farag1
}

\begin{abstract}
We evaluated the thermal regime and relative abundance of native and nonnative fish and invertebrates within Kelly Warm Spring and Savage Ditch, Grand Teton National Park, Wyoming. Water temperatures within the system remained relatively warm year-round with mean temperatures $>20{ }^{\circ} \mathrm{C}$ near the spring source and $>5{ }^{\circ} \mathrm{C}$ approximately $2 \mathrm{~km}$ downstream of the source. A total of 7 nonnative species were collected: Convict/Zebra Cichlid (Cichlasoma nigrofasciatum), Green Swordtail (Xiphophorus hellerii), Tadpole Madtom (Noturus gyrinus), Guppy (Poecilia reticulata), Goldfish (Carassius auratus), red-rimmed melania snail (Melanoides tuberculata), and American bullfrog tadpoles (Lithobates catesbeianus). Nonnative fish (Zebra Cichlids and Green Swordtails), red-rimmed melania snails, and bullfrog tadpoles dominated the upper $2 \mathrm{~km}$ of the system. Abundance estimates of the Zebra Cichlid exceeded $12,000 \mathrm{fish} / \mathrm{km}$ immediately downstream of the spring source. Relative abundance of native species increased moving downstream as water temperatures attenuated with distance from the thermally warmed spring source; however, nonnative species were captured $4 \mathrm{~km}$ downstream from the spring. Fish diseases were prevalent in both native and nonnative fish from the Kelly Warm Spring pond. Clinostomum marginatum, a trematode parasite, was found in native species samples, and the tapeworm Diphyllobothrium dendriticum was present in samples from nonnative species. Diphyllobothrium dendriticum is rare in Wyoming. Salmonella spp. were also found in some samples of nonnative species. These bacteria are associated with aquarium fish and aquaculture and are generally not found in the wild.
\end{abstract}

Resumen.-Evaluamos el régimen térmico y la abundancia relativa de peces e invertebrados nativos y no nativos en Kelly Warm Spring y Savage Ditch, en el Parque Nacional Grand Teton de Wyoming. La temperatura del agua dentro del sistema permaneció relativamente cálida durante todo el año con temperaturas medias de $>20^{\circ} \mathrm{C}$ cerca de su fuente de origen, y de $>5{ }^{\circ} \mathrm{C}$ aproximadamente a $2 \mathrm{~km}$ abajo de la fuente de origen del manantial. Colectamos un total de 7 especies no nativas: cíclido cebra (Cichlasoma nigrofasciatum), cola de espada verde (Xiphophorus hellerii), tadpole madtom (Noturus gyrinus), pez millón (Poecilia reticulata), pez dorado (Carassius auratus), melanoides (Melanoides tuberculata) y rana toro (Lithobates catesbeianus). Los peces no nativos (cíclidos cebra y cola de espada), los melanoides y las ranas toro dominaron los $2 \mathrm{~km}$ superiores del sistema. Las estimaciones sobre la abundancia del cíclido cebra excedieron los 12,000 peces/km en la zona inmediata río abajo del origen del manantial. La abundancia relativa de las especies nativas aumentó a medida que nos dirigimos río abajo y que la temperatura del agua se atenuó por la distancia de la fuente de origen del manantial, de aguas termales; sin embargo, capturamos especies no nativas $4 \mathrm{~km}$ río abajo del manantial. Las enfermedades de los peces fueron frecuentes, tanto en peces nativos como en no nativos del estanque Kelly Warm Spring. Hallamos en las muestras de especies nativas un parásito trematodo Clinostomum marginatum; mientras que la tenia Diphyllobothrium dendriticum estuvo presente en muestras de especies no nativas. La tenia Diphyllobothrium dendriticum es poco frecuente en Wyoming. La bacteria Salmonella también se encontró en algunas muestras de especies no nativas. Esta bacteria está asociada a peces de acuario y a la acuicultura, y generalmente no se encuentra en la naturaleza.

Kelly Warm Spring (KWS) is a natural thermal feature located near the southern boundary of Grand Teton National Park, Wyoming, USA, at an elevation of $2039 \mathrm{~m}$ above sea level. Despite this high elevation, the water temperature at the spring source remains approximately $25^{\circ} \mathrm{C}$ year-round.

Warm springs have been the target of introductions of nonnative aquatic species throughout the western United States, and KWS has been the recipient of illegal nonnative fish stocking since at least the mid-1960s (Deacon and Williams 1984, Courtenay et al. 1987). Recent National Park Service surveys of KWS have found multiple nonnative species, including the Guppy (Poecilia reticulata), Green Swordtail (Xiphophorus hellerii), Convict/Zebra Cichlid (Cichlasoma nigrofasciatum), Tadpole Madtom (Noturus gyrinus), Goldfish (Carassius auratus), red-rimmed melania (Melanoides

\footnotetext{
${ }^{1}$ U.S. Geological Survey, Columbia Environmental Research Center, Jackson Field Research Station, 1475 Fish Hatchery Road, Jackson, WY 83001

${ }^{2}$ Corresponding author. E-mail: david_harper@usgs.gov
} 
tuberculata), and American bullfrog (Lithobates catesbeianus). Several of these nonnative species have specific temperature tolerances that likely limit their spread beyond the spring (e.g., Swordtails, Cichlids, Guppies, and redrimmed melania snails). Other species that are more tolerant of cool water, may present a greater threat of invasion to the Greater Yellowstone Ecosystem (e.g., Goldfish, Tadpole Madtoms, and bullfrogs). In 2012, Goldfish and Tadpole Madtoms were collected within $0.5 \mathrm{~km}$ of the Snake River (Whaley unpublished data). If these species could colonize the Snake River, they may be able to successfully invade other habitats and expand their ranges within the park.

The goal of this research is to document the thermal regime within Kelly Warm Spring and the Savage Ditch system throughout the year and assess the longitudinal change in species composition of aquatic organisms from the spring source to the confluence with Ditch Creek $4 \mathrm{~km}$ downstream. We hypothesized that the relative abundance of nonnative species would decrease downstream as the water temperatures declined. There have been many research and assessment efforts to document the biota of KWS over the years; however, most documentation has remained as unpublished data and gray literature. Thus, another purpose of this manuscript is to compile historical data to inform future resource management decisions.

\section{MeTHODS}

Site Description and Sampling History

Water from the spring flows into a pond occupying approximately 0.40 surface hectares (1.0 acre), with a maximum depth of approximately $1.2 \mathrm{~m}$ (Fig. 1). The spring pond discharges into Savage Ditch, which drains into Ditch Creek and ultimately the Snake River, approximately $10 \mathrm{~km}$ downstream (Fig. 1). Kelly Warm Spring and the Savage Ditch complex were altered during the early 1900s before the park was established. During irrigation season (May to mid-October), water from Savage Ditch is diverted through an elevated flume over Ditch Creek, approximately $4.0 \mathrm{~km}$ below the spring, and is used to irrigate summer pasture. The remaining water from summer pastures enters Ditch Creek approximately $8 \mathrm{~km}$ below the KWS source during irrigation season.
From mid-October to May, water from KWS and Savage Ditch enters Ditch Creek approximately $4 \mathrm{~km}$ below the source.

Fisheries assessments of KWS conducted in 1968 revealed that the pond at the source of the spring contained the Utah Sucker (Catstomus ardens), Utah Chub (Gila atrari), Redside Shiner (Richardsonius balteatus), Longnose Dace (Rhinichthys cataractae), and Speckled Dace (Rhinichthys osculus) (Baldwin and Franta unpublished data). The Guppy was the only nonnative aquarium species collected. By the 1970s, monitoring surveys conducted by Grand Teton National Park found no Utah Suckers present in the springs. During sample collections in July 1984, thirty-seven Utah Chub and 2 Speckled Dace specimens were collected (Courtenay et al. 1987). Nonnatives captured included 65 Guppy specimens and 203 Green Swordtail specimens. Green Swordtail has not been recorded elsewhere in Wyoming (Courtenay et al. 1987). These findings suggest that nonnative fish are being deposited into Kelly Warm Springs from aquarium sources. In 1998, Convict/Zebra Cichlid and Tadpole Madtom were also collected in KWS by the Wyoming Game and Fish Department (Keifling unpublished data). Sampling by Grand Teton National Park found that Goldfish were also present in 2009 and 2012 (Whaley unpublished data; USDI 2014). In addition to introduced fish species, the redrimmed melania, a nonnative snail, and the American bullfrog were collected, indicating that additional species have been released into KWS since 1999 (Hotchkiss and Laske 2011).

Water temperature was monitored at 5 sites within KWS and Savage Ditch from October 2014 to April 2016 between the KWS pond (KWS-1 hereafter) and the flume diversion on Savage Ditch. One site was monitored in Ditch Creek (KWS-6) approximately $1 \mathrm{~km}$ below the flume diversion (Fig. 1). Temperatures were recorded hourly with Onset ${ }^{\mathrm{TM}}$ HOBO TidBit temperature loggers (Onset Computer Corporation, Bourne, MA) attached to the stream bank and weighted with plasticcoated steel cable. Water quality data were also collected on 8 October 2015 in Savage Ditch at KWS-3 for dissolved oxygen, conductivity, $\mathrm{pH}$, alkalinity, and hardness as $\mathrm{CaCO}_{3}$.

Fish assemblage data were collected on 5-7 October 2015. At KWS-1, fish were collected with beach seines $(1.2 \mathrm{~m} \times 30 \mathrm{~m}, 5-\mathrm{mm}$ 

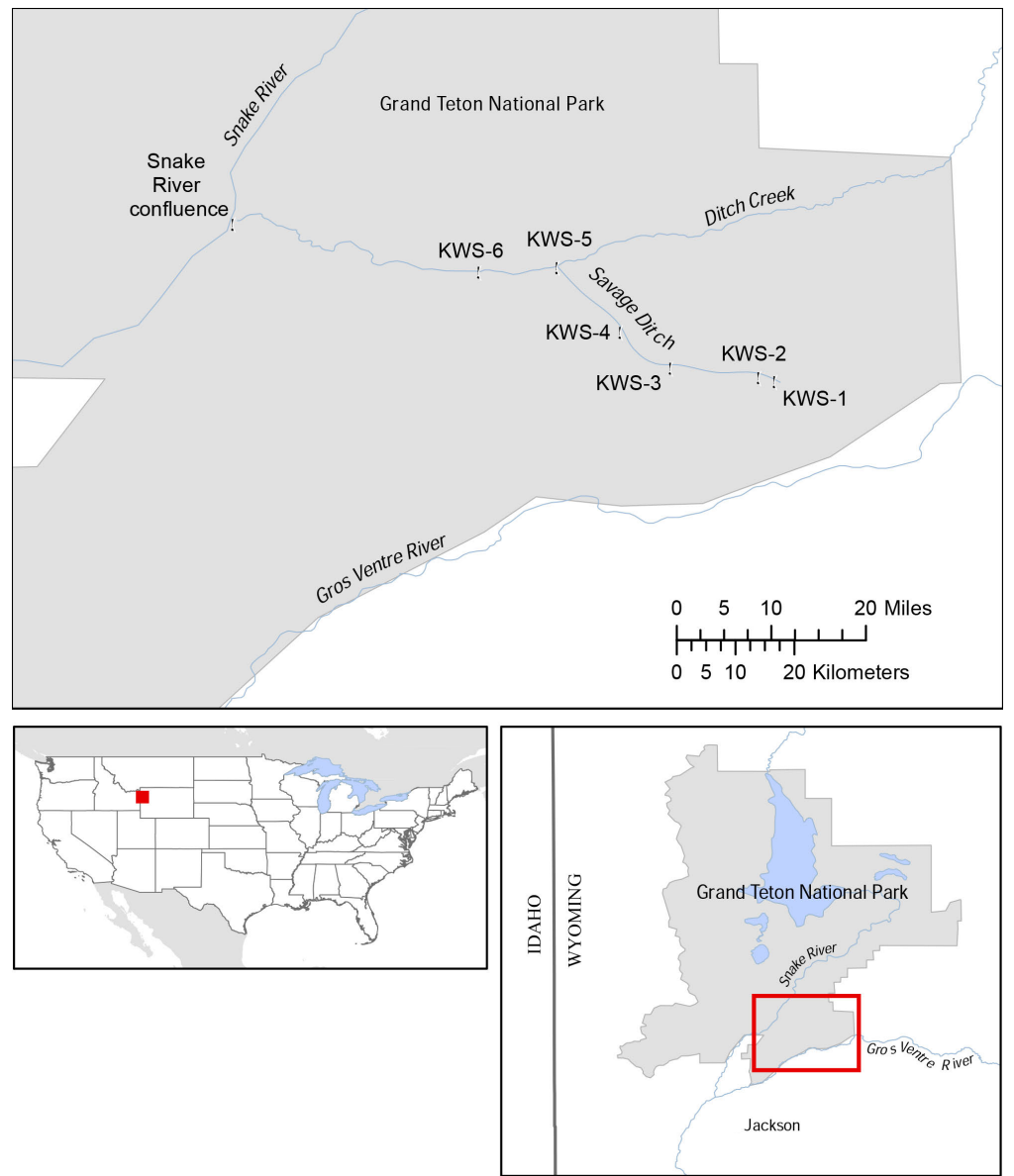

Fig. 1. The Kelly Warm Spring and Savage Ditch study area, Grand Teton National Park, Wyoming.

mesh), dip nets (0.5- $\mathrm{m}^{2}$ dip nets, $900-\mu \mathrm{m}$ mesh), and backpack electrofishing gear. Because of the presence of dense algae mats that allowed many fish to escape capture, the large numbers of fish present, and the large sampling effort required, no population estimate was determined. However, the relative abundances of native and nonnative fish species were assessed.

Because noticeable lesions and "popeye" have been observed in fish from the KWS-1, a subsample of native and nonnative fish was collected for disease assessment. Five specimens each of Redside Shiner, Utah Chub, Speckled Dace, Convict/Zebra Cichlid, Green Swordtail, and Goldfish were collected. Sampled fish were shipped live overnight to the Wyoming Game and Fish Wildlife Forensics and Fish Health Laboratory in Laramie, Wyoming, for necropsy and disease assessment. At the laboratory, visual external exams, skin scrapes, and gill exams were performed. Additionally, histological analysis of wet mounts of gill, arterial blood, descending intestine, spleen, and kidney were conducted, and assessments of bacterial cultures from internal organs and gills were performed.

Within the Savage Ditch, we assessed species abundance at 3 sites, with 2 sites selected for multiple-pass removal population estimates (KWS-2 and KWS-5) using the 2-pass modified depletion method (Zippin 1958). Sampled reaches within Savage Ditch were $91 \mathrm{~m}$ (300 feet) in length, with block nets placed at the upstream and downstream ends of the reach. At each reach, 2 passes were made with 2 backpack electrofishing units operating side by side and 2 additional netters capturing stunned fish. At a third site within Savage Ditch (near KWS-3), a 91-m 
TABLE 1. Sampling techniques, dates, number of samples collected, and sampling locations within Kelly Warm Spring and the Savage Ditch, 2014-2015, in Grand Teton National Park, Wyoming, USA.

\begin{tabular}{|c|c|c|c|}
\hline Sampling technique & Dates sampled/deployed & $\begin{array}{l}\text { Number of } \\
\text { samples/loggers/effort }\end{array}$ & Location \\
\hline Temperature logger & 6 Oct 2014 to 27 Oct 2015 & 1 per site hourly & KWS- $1,3,4,5,6$ \\
\hline Electrofishing & 5 Oct 2015 & 6-pass & KWS-1 \\
\hline Electrofishing & 6 Oct 2015 & 2 -pass & KWS-2, 5 \\
\hline Electrofishing & 7 Oct 2015 & 1-pass & KWS-3 \\
\hline Beach seine & 5 Oct 2015 & 6 seine pulls & KWS-1 \\
\hline Dip net & 5 Oct 2015 & 1 hour & KWS-1 \\
\hline Plate sampler & 2 Sep 2015 to 1 Oct 2015 & 4 per site & KWS- $1,2,4,6$ \\
\hline Plate sampler & 21 Apr 2016 to 1 Jun 2016 & 4 per site & KWS- $1,3,4,5$ \\
\hline Stovepipe sampler & $13-14$ Oct 2015 & 4 per site & KWS- $1,3,4,5,6$ \\
\hline Kick net & $13-14$ Oct 2015 & 4 per site & KWS- $1,3,4,5,6$ \\
\hline
\end{tabular}

Study area site locations

\begin{tabular}{lll}
\hline Site number & Latitude & Longitude \\
\hline KWS-1 & $43^{\circ} 38^{\prime} 21.64^{\prime \prime} \mathrm{N}$ & $110^{\circ} 36^{\prime} 58.81^{\prime \prime} \mathrm{W}$ \\
KWS-2 & $43^{\circ} 38^{\prime} 24.49^{\prime \prime} \mathrm{N}$ & $110^{\circ} 37^{\prime} 58.15^{\prime \prime} \mathrm{W}$ \\
KWS-3 & $43^{\circ} 38^{\prime} 29.48^{\prime \prime} \mathrm{N}$ & $110^{\circ} 37^{\prime} 59.63^{\prime \prime} \mathrm{W}$ \\
KWS-4 & $43^{\circ} 38^{\prime} 50.45^{\prime \prime} \mathrm{N}$ & $110^{\circ} 38^{\prime} 28.78^{\prime \prime} \mathrm{W}$ \\
KWS-5 & $43^{\circ} 39^{\prime} 28.24^{\prime \prime} \mathrm{N}$ & $110^{\circ} 39^{\prime} 05.58^{\prime \prime} \mathrm{W}$ \\
KWS-6 & $43^{\circ} 39^{\prime} 25.51^{\prime \prime} \mathrm{N}$ & $110^{\circ} 39^{\prime} 51.27^{\prime \prime} \mathrm{W}$ \\
\hline
\end{tabular}

section was sampled with one pass without block nets to assess species composition and relative abundance. At all sampling sites, collected fish were held in buckets and identified by species. Length and weight were recorded for the first 200 samples of each species, and total number and species were recorded for the remaining individuals. Native species were returned alive to each reach after each sampling effort. Nonnative species were euthanized with MS-222.

Macroinvertebrate habitat within KWS-1 and the Savage Ditch is highly variable, with dense weed mats and fine sediments dominating the pond and riffle/run habitat within the flowing sections. To maximize macroinvertebrate diversity and effectively cover the variable habitat found within the pond and stream system, plate samplers, stovepipe samplers, kick nets, and dip nets were used. Plate samplers consisted of $9 \times 9 \times 1.5$-cm grooved wooden plates bolted together with varying numbers of metal washers between plates to create interstitial spaces of varying thicknesses (Fullner 1971). Macroinvertebrates were also sampled with an approximately $500-\mathrm{mm}$ stovepipe sampler and a $0.5-\mathrm{m}^{2}$ kick net $(900-\mu \mathrm{m}$ mesh). Collected organisms for all samples were placed in 500-mL HDPE containers and preserved in $70 \%$ ethanol for enumeration in the laboratory. Macroinvertebrates were identified

to genus and species when possible (Meritt and Cummings 1978). Plate samplers were also deployed 29 April through 1 June 2016 at KWS-1, 3, 4, and 5. Samples collected during spring 2016 were identified in the field for a general comparison with species composition data collected during fall 2015 sampling. Sampling techniques, dates, numbers of samples collected per site, and sampling locations are presented in Table 1.

\section{RESULTS}

Water temperatures near the outflow of KWS-1 ranged from $19{ }^{\circ} \mathrm{C}$ to $31{ }^{\circ} \mathrm{C}$. Within the Savage Ditch, water temperatures ranged from $10{ }^{\circ} \mathrm{C}$ to $34^{\circ} \mathrm{C}$ at KWS $-3,1^{\circ} \mathrm{C}$ to $40{ }^{\circ} \mathrm{C}$ at KWS $-4,1{ }^{\circ} \mathrm{C}$ to $35^{\circ} \mathrm{C}$ at KWS-5, and $1{ }^{\circ} \mathrm{C}$ to $32{ }^{\circ} \mathrm{C}$ at KWS-6 (Fig. 2). Data gaps shown in Fig. 2 are due to logger failure and vandalism of TidBit temperature loggers. Water quality data for samples collected on 8 October 2015 were as follows: dissolved oxygen $=10.12 \mathrm{mg} / \mathrm{L}$, conductivity $=390 \mu \mathrm{S} / \mathrm{cm}, \mathrm{pH}=8.52$, hardness $=188 \mathrm{mg} / \mathrm{L}$ as $\mathrm{CaCO}_{3}$, and alkalinity $=$ $128 \mathrm{mg} / \mathrm{L}$ as $\mathrm{CaCO}_{3}$.

At KWS-1, a total of 1223 fish, 8 adult bullfrogs, and 132 bullfrog tadpoles were collected. Goldfish were observed avoiding capture and are likely underrepresented. At KWS-2, a total of 1276 fish, 23 adult bullfrogs, and 12 bullfrog tadpoles were sampled. Estimated fish abundance of all species at KWS-2 was 1937 fish $/ 100 \mathrm{~m}$, or 19,368 fish $/ \mathrm{km}$.

Fish were sampled at KWS-3 using one pass with electrofishing gear. A total of 281 fish, 1 adult bullfrog, and 7 bullfrog tadpoles were sampled. Because only one pass was performed and block nets were not used at this site, no abundance estimates were calculated. 

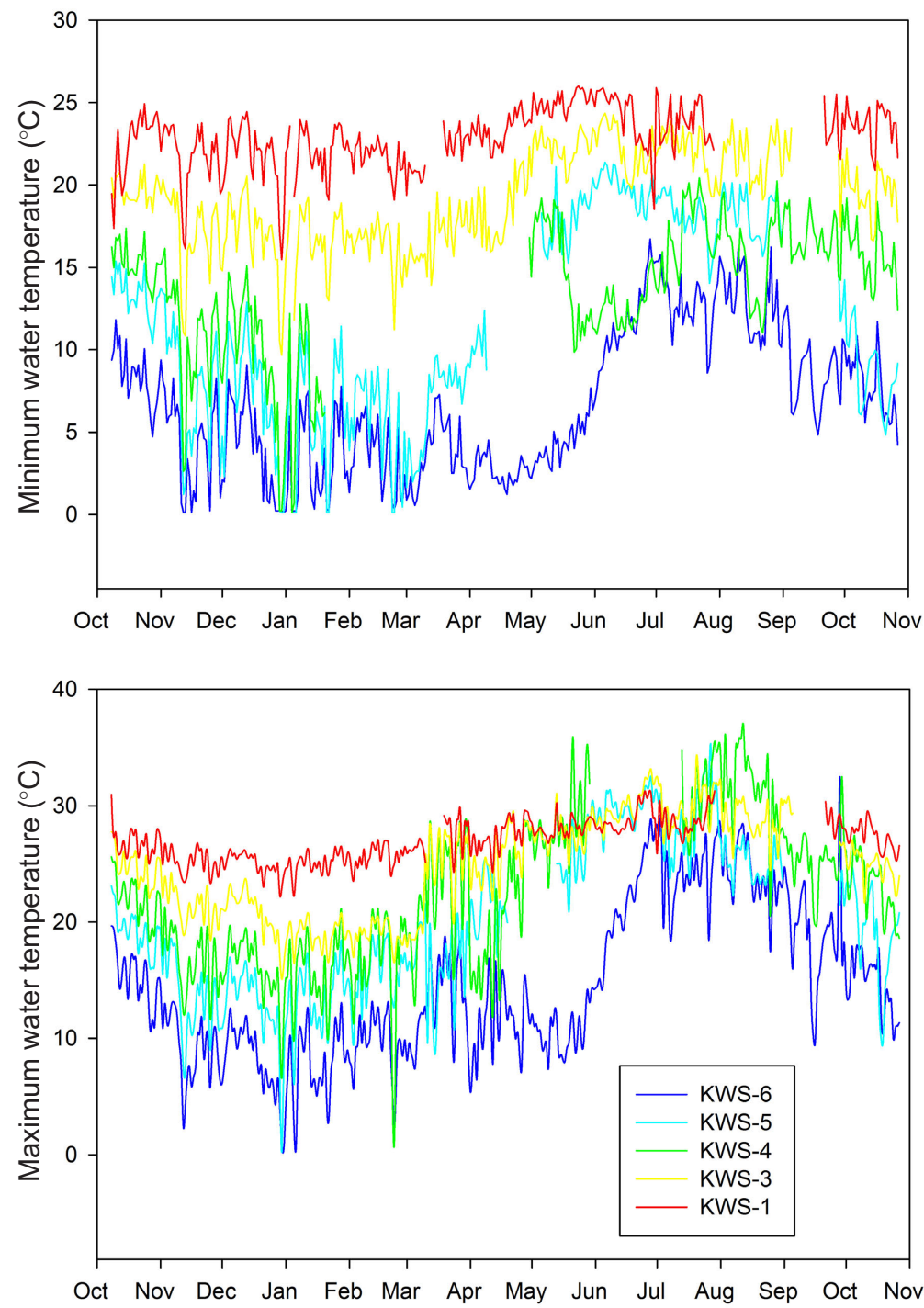

Fig. 2. Minimum and maximum daily water temperatures recorded October 2014 through October 2015 at 5 sites in Kelly Warm Spring and Savage Ditch, Grand Teton National Park, Wyoming.

At KWS-5, a total of 609 fish were sampled. Fish and bullfrog abundance data for all sampled sites are presented in Table 2, and percent native and nonnative species collected at each site is presented in Table 3 .

Invertebrate species collected from plate samplers deployed during fall 2015 were dominated by snails (red-rimmed melania, Planorbidae, Planorbella) at all sites within KWS (Table 4). Only a few individual insects, Chironomidae and Tipulidae, were sampled in KWS and the Savage Ditch. Sampling with stovepipe samplers and kick nets resulted in collection of similar macroinvertebrate genera, with snails dominating the KWS and Savage Ditch sites and a greater species diversity in Ditch Creek (KWS-6) immediately downstream of the confluence with Savage Ditch (Tables 5 , 6). Spring sampling in 2016 found an invertebrate assemblage similar to that found by fall sampling in 2015. Plate samplers deployed April through June 2016 in KWS and Savage Ditch collected red-rimmed melania (48) and Planorbella (2) snails in KWS-1, red-rimmed melania (>100) and no other species at KWS-3, Planorbella (20) and chronomidae (1) at KWS-4, 
TABLE 2. Sampling data and abundance estimates from fish sampled in Kelly Warm Spring and Savage Ditch, Grand Teton National Park, Wyoming, USA, 5-7 October 2015. Fish were sampled with backpack electrofishing gear, and density estimates were calculated using the 2-pass removal method (Zippen 1958).

\begin{tabular}{|c|c|c|c|c|c|c|c|c|}
\hline \multirow[b]{2}{*}{ Taxon } & \multirow{2}{*}{$\begin{array}{c}\text { KWS-1 } \\
\text { No. } \\
\text { sampled }\end{array}$} & \multicolumn{3}{|c|}{ KWS-2 } & \multirow{2}{*}{ 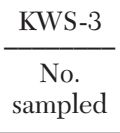 } & \multicolumn{3}{|c|}{ KWS-5 } \\
\hline & & $\begin{array}{c}\text { No. } \\
\text { sampled }\end{array}$ & $\begin{array}{c}\text { Density } \\
\text { (no./91.44 m) }\end{array}$ & $\begin{array}{l}\text { Density } \\
(\text { no./km) }\end{array}$ & & $\begin{array}{c}\text { No. } \\
\text { sampled }\end{array}$ & $\begin{array}{c}\text { Density } \\
\text { (no./91.44 m) }\end{array}$ & $\begin{array}{l}\text { Density } \\
\text { (no./km) }\end{array}$ \\
\hline Adult bullfrog & 8 & 23 & & & 1 & & & \\
\hline Bullfrog tadpole & 132 & 12 & & & 7 & & & \\
\hline Goldfish & 7 & 1 & & & 25 & 10 & 10 & 111 \\
\hline Guppy & 23 & & & & 11 & & & \\
\hline Longnose Dace & & & & & 77 & 1 & & \\
\hline Tadpole Madtom & 2 & 17 & 18 & 195 & 30 & 36 & 42 & 462 \\
\hline Mountain Sucker & & & & & 1 & 2 & & \\
\hline Redside Shiner & 68 & 72 & 200 & 2188 & 9 & 125 & 138 & 1505 \\
\hline Speckled Dace & 3 & 205 & 307 & 3361 & 68 & 295 & 368 & 4029 \\
\hline $\begin{array}{l}\text { Snake River } \\
\text { Cutthroat Trout }\end{array}$ & & & & & 27 & 1 & & \\
\hline Green Swordtail & 535 & 29 & 40 & 441 & 1 & 33 & 38 & 420 \\
\hline Utah Chub & 19 & 36 & 39 & 429 & 7 & 103 & 104 & 1140 \\
\hline Zebra Cichlid & 566 & 916 & 1166 & 12,758 & 25 & 3 & & \\
\hline
\end{tabular}

TABle 3. Percent native and nonnative fish species collected from Kelly Warm Spring and Savage Ditch, Grand Teton National Park, Wyoming, USA, 5-7 October 2015. Samples were collected with beach seines, dip nets, and backpack electrofishing gear.

\begin{tabular}{lcc}
\hline Site & $\begin{array}{c}\text { Percent } \\
\text { native fish }\end{array}$ & $\begin{array}{c}\text { Percent } \\
\text { nonnative fish }\end{array}$ \\
\hline KWS-1 & 7.4 & 92.6 \\
KWS-2 & 24.6 & 75.4 \\
KWS-3 & 71.0 & 29.0 \\
KWS-5 & 86.5 & 13.5 \\
\hline
\end{tabular}

and Planorbella (37) and Chironomidae (8) at KWS-5. Ditch Creek immediately downstream of the confluence with Savage Ditch (KWS-6) was not sampled in 2016.

Fish diseases were prevalent in both native and nonnative fish from KWS-1. Externally, native species had bubble-like lesions and external rod-shaped bacteria, while nonnative species had no discernible external parasites. Internally, native species showed heavy amounts of bacteria in wet mounts of spleen, kidney, and descending intestine. In nonnative species, wet mounts of gills showed healthy, feathery gills with moderate amounts of bacteria, wet mounts of spleen showed moderate amounts of bacteria, and wet mounts of kidneys and descending intestines showed heavy amounts of bacteria. Internal tapeworms were present in some samples. Pathogens found were Aeromonas hydrophila (bacteria in native and nonnative samples), Salmonella spp. (bacteria in nonnative samples), Pseudomonas oryzihabitans (bacteria in native samples), Pseudomonas aeruginosa (bacteria in native samples), Diphyllobothrium dendriticum (parasite in nonnative samples), and Clinostomum marginatum (parasite in native samples).

\section{DisCussion}

Water temperatures within KWS and the Savage Ditch system remain warm (mean temperature $>10{ }^{\circ} \mathrm{C}$ ) downstream approximately $4 \mathrm{~km}$ below the outflow from March through October. The composition of aquatic species in KWS and Savage Ditch reflect the temperature regime, as nonnative species dominate the pond and ditch upstream where the thermal regime is elevated. Cichlids, Green Swordtails, and red-rimmed melania were the most frequently collected aquatic organisms in the upper reaches of KWS and Savage Ditch. Approximately $2 \mathrm{~km}$ downstream (KWS-3), water temperatures became cooler during winter months. While nonnative red-rimmed melania and Tadpole Madtom were still among the most abundant species, native fishes and snails increased in both number and relative abundance. At $4 \mathrm{~km}$ below the springs outflow (KWS-5), nonnative species were less common but still present, and native species dominated. It should be noted that fish samples collected prior to 1970 showed the presence of native Utah Sucker within KWS; however, the species has not been collected there since 1968. Since these 
TABLE 4. Invertebrates collected with plate samplers in the Kelly Warm Spring study area, October 2015, Grand Teton National Park, Wyoming, USA.

\begin{tabular}{llllr}
\hline Site & Order & Family & Genus & No. sampled \\
\hline KWS-1 & Neotaenioglossa & Thiaridae & Melanoides & 223 \\
& Basommataphora & Planorbidae & Planorbella & 40 \\
& Diptera & Chironomidae & & 2 \\
& Basommataphora & Physidae & & 2 \\
& Ephemeroptera & Thiaridae & Melanoides & 1 (carapace) \\
KWS-2 & Neotaenioglossa & Planorbidae & Planorbella & 1001 \\
& Basommatophora & Lymnaeidae & Melanoides & 30 \\
KWS-4 & Basommatophora & Thiaridae & 1 \\
& Neotaenioglossa & Planorbidae & Glanorbella & 177 \\
& Basommatophora & Planorbidae & 21 \\
KWS-6 & Basommatophora & Physidae & 51 \\
& Basommatophora & Brachycentridae & Brachycentrus & 6 \\
& Trichoptera & Hydropsychidae & Arctopsyche & 9 \\
& Trichoptera & Lepidostomatidae & Lepidostoma & 11 \\
& Trichoptera & Leptophlebiidae & Ephemerella & 132 \\
& Ephemeroptera & Ephemerellidae & Isoperla & 4 \\
& Ephemeroptera & Perlodidae & Claassenia & 1 \\
& Plecoptera & Perlidae & & 1 \\
& Plecoptera & & & 1 \\
& & & &
\end{tabular}

TABLE 5. Invertebrates collected with kick nets and stovepipe samplers in Kelly Warm Spring and Savage Ditch, October 2015, Grand Teton National Park, Wyoming, USA.

\begin{tabular}{llllr}
\hline Site & Order & Family & Genus & No. sampled \\
\hline KWS-1 & Neotaenioglossa & Thiaridae & Melanoides & 135 \\
& Diptera & Chironomidae & Tricorythodes & 13 \\
KWS-3 & Ephemeroptera & Leptohyphidae & Melanoides & 1 \\
& Neotaenioglossa & Thiaride & Planorbella & 19 \\
& Basommatophora & Planorbidae & Gyralus & 16 \\
& Basommatophora & Planorbidae & & 39 \\
& Diptera & Tipulidae & Mayatrichia & 1 \\
KWS-4 & Diptera & Chironomidae & Melanoides & 1 \\
& Trichoptera & Hydroptilidae & Planorbella & 2 \\
KWS-5 & Neotaenioglossa & Thiaridae & Planorbella & 13 \\
& Basommatophora & Planorbidae & & 16 \\
& Diptera & Tipulidae & & 5 \\
& Basommatophora & Planorbidae & & 21 \\
& Basommatophora & Lymnaeidae & Tipulidae & 1 \\
\hline
\end{tabular}

early sampling efforts, the abundance and number of nonnative species present have increased, indicating likely displacement of the Utah Sucker by nonnative species.

Because of the cold minimum water temperatures nearing $0{ }^{\circ} \mathrm{C}$ at $\mathrm{KWS}-5$ and below, warm water obligate species, such as Green Swordtails, Convict Cichlids, and Guppies are unlikely to become established or expand their range. Green Swordtails prefer temperatures from $20{ }^{\circ} \mathrm{C}$ to $25{ }^{\circ} \mathrm{C}$, but can tolerate temperatures down to $6{ }^{\circ} \mathrm{C}$ to $7^{\circ} \mathrm{C}$ (Tuckett et al. 2016). Convict Cichlids prefer temperatures $24{ }^{\circ} \mathrm{C}$ to $28^{\circ} \mathrm{C}$, but can survive temperatures as low as $7.8^{\circ} \mathrm{C}$ (Minckley and Marsh 2009).
Goldfish have been collected throughout KWS and Savage Ditch and have been found $<0.5 \mathrm{~km}$ from the Snake River (Whaley unpublished data). The potential for colonization of goldfish outside the KWS and Savage Ditch may present a threat to native species in the Greater Yellowstone Ecosystem. While Goldfish prefer warm water $\left(>20{ }^{\circ} \mathrm{C}\right)$, they can tolerate water temperatures as low as 0.3 ${ }^{\circ} \mathrm{C}$ (Ford and Beitinger 2005). Goldfish have established self-sustaining populations in every U.S. state outside of Alaska and are a growing problem in Canadian lakes and ponds (Nico et al. 2016). In the wild, outside the confines of a fish tank and limited food, goldfish can reach 
TABLE 6. Invertebrates collected with kick nets in Ditch Creek downstream of the Savage Ditch Confluence (KWS-6), October 2015, Grand Teton National Park, Wyoming, USA.

\begin{tabular}{|c|c|c|c|c|}
\hline Site & Order & Family & Genus & No. sampled \\
\hline KWS-6 & Basommatophora & Planorbidae & Gyralus & 4 \\
\hline KWS-6 & Coleoptera & Elmidae & Dubiraphia & 6 \\
\hline KWS-6 & Coleoptera & Elmidae & Lara & 1 \\
\hline KWS-6 & Diptera & Simulidae & Simulium & 2 \\
\hline KWS-6 & Diptera & Chironomidae & & 6 \\
\hline KWS-6 & Diptera & Tipulidae & Hexatoma & 7 \\
\hline KWS-6 & Diptera & Tipulidae & Tipula & 6 \\
\hline KWS-6 & Ephemeroptera & Ameletidae & Ameletus & 2 \\
\hline KWS-6 & Ephemeroptera & Baetidae & Baetis & 4 \\
\hline KWS-6 & Ephemeroptera & Ephemerellidae & Drunella & 7 \\
\hline KWS-6 & Ephemeroptera & Ephemerellidae & Ephemerella & 2 \\
\hline KWS-6 & Ephemeroptera & Heptageniidae & Epeorus & 1 \\
\hline KWS-6 & Ephemeroptera & Heptageniidae & Rithrogena & 4 \\
\hline KWS-6 & Ephemeroptera & Leptophlebliidae & Leptophlebia & 17 \\
\hline KWS-6 & Ephemeroptera & Leptophlebliidae & Paraleptophlebia & 7 \\
\hline KWS-6 & Plecoptera & Chloroperlidae & Alloperla & 3 \\
\hline KWS-6 & Plecoptera & Chloroperlidae & Sweltsa & 1 \\
\hline KWS-6 & Plecoptera & Leuctridae & Perlomyia & 1 \\
\hline KWS-6 & Plecoptera & Nemouridae & Zapada & 1 \\
\hline KWS-6 & Plecoptera & Perlidae & Claassenia & 8 \\
\hline KWS-6 & Plecoptera & Perlodidae & Isoperla & 2 \\
\hline KWS-6 & Plecoptera & Perlodidae & Osobenus & 1 \\
\hline KWS-6 & Plecoptera & Perlodidae & Setrena & 1 \\
\hline KWS-6 & Plecoptera & Pteronarcyidae & Pteronarcella & 3 \\
\hline KWS-6 & Trichoptera & Brachycentridae & & 2 \\
\hline KWS-6 & Trichoptera & Hydropyschidae & Arctopsyche & 29 \\
\hline KWS-6 & Trichoptera & Lepidostomatidae & Lepidostoma & 4 \\
\hline
\end{tabular}

up to $590 \mathrm{~mm}$ total length and weigh up to $3 \mathrm{~kg}$ (IGFA 2001). Additionally, goldfish frequently hybridize with the Common Carp (Cyprinus carpio), giving rise to individuals that are intermediate in morphology between the 2 parent species (Nico et al. 2016). The Goldfish is a benthic herbivore whose behavior often results in visible increases in turbidity and decreases in aquatic vegetation (Richardson et al. 1995). Due to its omnivorous feeding habits, it has been implicated in the decline of native fishes, invertebrates, and aquatic macrophytes (Richardson et al. 1995).

The Tadpole Madtom is also present throughout KWS and Savage Ditch, as well as lower Ditch Creek (Whaley unpublished data). While considered a "warm water" species, its native range extends from the upper Midwest and eastern United States, to the Canadian provinces of Ontario, Manitoba, and Saskatchewan, indicating its tolerance for cold water temperatures (Scott and Crossman 1973, Fuller 2016). Nonnative populations currently exist in the U.S. states of Colorado, Idaho, Oregon, and Washington. Because of the species' tolerance of cold water, it may have the potential for expansion outside of KWS and the Savage Ditch system in Grand Teton National Park and the Greater Yellowstone Ecosystem.

The presence of nonnative fish in KWS also causes concern for the spread of fish disease in and around KWS. Diphyllobothrium dendriticum, a tapeworm documented in nonnative fish inhabiting KWS, is most concerning because it is generally not found in Wyoming (Brandon Taro, Wyoming Game and Fish Department, personal communication). The only previously documented presence of this tapeworm was in Lake Alice near Big Piney, Lincoln County, Wyoming, in 2006. Its life cycle requires consumption of fish hosts by birds or mammals, which pass eggs through feces to the water, which are then consumed by copepods, wherein the larval stage of the tapeworm develops and is then consumed by fish, which are in turn consumed by birds or mammals, completing the life cycle (Curtis et al. 1988). Diphyllobothrium dendriticum fish hosts are generally salmonids, but this parasite has been observed in many families of fishes, including the nonnative species collected in 
KWS (Kuchta et al. 2013). The tapeworm infrequently parasitizes humans, but cases worldwide have been associated with the consumption of raw or undercooked fish. Diphyllobothrium dendriticum is an opportunistic tapeworm and may have the ability to jump to a new species, though that was not documented in this study. Because the nonnative red-rimmed melania is a host for trematodes, it is likely a host of $D$. dendriticum in KWS.

Salmonella is another concern because it is considered an aquarium or aquaculture pathogen and is not generally found in wild populations. A large burden of Salmonella is required for the bacteria to persist beyond a few days following exposure of the fish to contaminated feed (Nesse et al. 2005). The documentation of Salmonella from multiple samples from KWS may indicate that it is present at a high density. Salmonella is another pathogen that has the potential to spread to other species, though that was not documented in the current study.

It should be noted that the trematode fluke Clinostomum marginatum, or Yellow Grub, which was detected in native fish, is not often found in wild fish in Wyoming. However, it is not considered a concern because wild fish seem to tolerate large loads of this pathogen. Yellow Grub is generally considered harmless to humans, but some species of Clinostomum have infected humans who have consumed raw fish (Park et al. 2009). Snails in the family Planorbidae, which are present in KWS, are likely the intermediate hosts of Yellow Grub.

Red-rimmed melania snails are native to northern Africa but are invasive throughout the western United States and are common invaders of springs and warm ponds (Benson and Neilson 2016). Red-rimmed melania outcompete native gastropods, resulting in displacement or eradication of native species, and are a known vector of trematode parasites of fish and other species (De Marco 1999, Mitchell et al. 2007). These snails can briefly tolerate temperatures down to $8{ }^{\circ} \mathrm{C}$ but are vulnerable to prolonged exposure $(12 \mathrm{~d})$ at $13{ }^{\circ} \mathrm{C}$. While red-rimmed melania may be limited to the upper reaches of KWS and the Savage Ditch by water temperature, their continued presence may provide a reservoir population for transport to other thermally stable springs and environments within the Greater Yellowstone Ecosystem. This potential mobility is particularly problematic given the red-rimmed melania's demonstrated ability to outcompete native gastropods.

Besides the threat of spread, nonnative fish and invertebrates appear to have already resulted in the displacement and decreased abundance of native species within KWS and Savage Ditch. Sampling of KWS in 1968 found many native species, including the Utah Sucker, and the only nonnative species collected at that time was the Guppy (Baldwin and Franta unpublished data). Each sampling effort in the ensuing years has found no Utah Suckers, but rather increasing varieties and numbers of nonnative species and fewer native species. While no relative abundance data was collected during early samples, current data show a dominance of nonnative species in the upper reaches of KWS and Savage Ditch. These data clearly indicate that nonnative species are outcompeting and displacing native species in a water body within Grand Teton National Park.

There is broad agreement across the scientific community that climate change is occurring, resulting in warmer temperatures of temperate water bodies (Walsh et al. 2014). These changes will result in higher water temperatures and increased frequency of large storm events, which may create conditions more suitable to warm water species (Poff et al. 2002). Rahel and Olden (2008) hypothesized that climate change may allow species that are present but not currently problematic and species that are limited by seasonally unfavorable conditions to expand their ranges. Additionally, Tuckett et al (2016) found that Green Swordtails collected from feral populations exhibited increased cold water tolerance, which may affect the potential range of invasive fish species. If water temperatures continue to increase as predicted, KWS could provide a reservoir for the expansion of species tolerant of cool water, such as Goldfish and Tadpole Madtoms, to the Snake River.

\section{ACKNOWLEDGMENTS}

We would like to thank Chad Whaley, Millie Jimenez, and Kathy Mellander from Grand Teton Nation Park, and Tracy Stephens, Chance Roberts, and John Heckel from the Wyoming Game and Fish Department for assistance with fish sampling. Additional thanks go to Brandon 
Taro from the Wyoming Game and Fish Department for conducting histological analysis and laboratory disease identification. Special thanks also to Callahan Jobe for her work in the field and especially with macroinvertebrate identification, and to Page Anderson. We thank Kimberly Chojnacki for constructing the map. This work would not have been possible without the support of Sue Consolo Murphy, Grand Teton Nation Park. Funding for this research was provided by the National Park Service, USGS/ NPS Interagency Agreement P15PG00149. Any use of trade, firm, or product names is for descriptive purposes only and does not imply endorsement by the U.S. Government.

\section{Literature Cited}

Benson, A.J., And M.E. Neilson. 2016. Melanoides tuberculata. USGS nonindigenous aquatic species database, Gainesville, FL; [revised 28 February 2013, accessed 13 September 2016]. http://nas.er.usgs.gov/ queries/Factsheet.aspx?speciesID = 1037

Courtenay, W.R., JR., C.R. Robins, R.M. Bailey, and J.E. DEACON. 1987. Records of exotic fishes in Idaho and Wyoming. Great Basin Naturalist 47:523-526.

Curtis M.A., M.E. Rau, C.E. Tanner, R.K. Prichard, and G.M. Faubert. 1988. Parasitic zoonoses in relation to fish and wildlife harvesting by Inuit communities in northern Quebec, Canada. Arctic Medical Research 47:693-696.

Deacon, J.E., and J.E. Williams. 1984. Annotated list of the fishes of Nevada. Proceedings of the Biological Society of Washington 97:103-118

DE Marco, P., JR. 1999. Invasion by the introduced aquatic snail Melanoides tuberculata (Muller, 1774) (Gastropoda: Prosobranchia: Thiaridae) of the Rio Doce State Park, Minas Gerais, Brazil. Studies on Neotropical Fauna and Environment 34:186-189.

Ford, T., AND T.L. Beitinger. 2005. Temperature tolerance in the goldfish, Carassius auratus. Journal of Thermal Biology 30:147-152.

FULLER, P. 2016. Noturus gyrinus. USGS nonindigenous aquatic species database, Gainesville, FL; [revised 19 April 2006, accessed 26 September 2016]. http://nas.er.usgs.gov/queries/factsheet.aspx?Species $\mathrm{ID}=747$

FUlLnER, R.W. 1971. A comparison of macroinvertebrates collected by basket and modified multipleplate samplers. Water Pollution Control Federation 43:494-499.

Hotchiss, E., AND S. LASke. 2011. Status of native and invasive populations in Kelly Warm Spring, Grand Teton National Park, WY. University of Wyoming, Laramie, WY.

[IGFA] International Game Fish Association. 2001. Database of IGFA angling records until 2001. IGFA, Fort Lauderdale, FL.

Kuchta, R., J. Brabec, P. KubáčKová, and T. Scholz. 2013. Tapeworm Diphyllobothrium dendriticum (Cestoda) - neglected or emerging human parasite? PLOS Neglected Tropical Diseases 7(12):e2535. https://doi.org/10.1371/journal.pntd.0002535
Merritt, R.W. and K.W. Cummins. 1978. An introduction to the aquatic insects of North America. Kendall Hunt Publication Co., Dubuque, IA.

MinCKLEY, W.L., AND P.C. MARSH. 2009. Inland fishes of the greater Southwest: chronicle of a vanishing biota. University of Arizona Press, Tucson, AZ.

Mitchell, A.J., M.S. Hobbs, and T.M. Brandt. 2007. The effect of chemical treatments on red-rim melania Melania tuberculata, an exotic aquatic snail that serves as a vector of trematodes to fish and other species in the USA. North American Journal of Fisheries Management 27:1287-1293.

Nesse, L.L., T. Lovold, B. Bergsjo, K. Nordby, C. WalLace, and G. Holstad. 2005. Persistence of orally administered Salmonella enterica serovars Agona and Montevideo in Atlantic salmon (Salmo salar L.) Journal of Food Protection 68:1336-1339.

Nico, L.G., P.J. SChOFIELD, J. LARSON, T.H. MAKLED, AND A. Fusaro. 2016. Carassius auratus. USGS nonindigenous aquatic species database, Gainesville, FL; [revised 2 August 2013, accessed 13 September 2016]. http://nas.er.usgs.gov/queries/factsheet.aspx? SpeciesID $=508$

Park, C.W., J.S. Kim, H.S. JoO, and J. Kim. 2009. A human case of Clinostomum complanatum infection in Korea. Korean Journal of Parasitology 47:401-404.

PofF, N.L., M.M. BRinson, AND J.W. DaY JR. 2002. Aquatic ecosystems and global climate change: potential impacts on inland freshwater and coastal wetland ecosystems in the United States. Pew Center on Global Climate Change, Arlington, VA; [accessed 28 September 2016]. http://www.c2es.org/publications/ aquatic-ecosystems-and-climate-change

Rahel, FJ., and J.D. Olden. 2008. Assessing the effects of climate change on aquatic invasive species. Conservation Biology 22:521-533.

Richardson, M.J., F.G. Whoriskey, and L.H. Roy. 1995. Turbidity generation and biological impacts of an exotic fish Carassius auratus, introduced into shallow seasonally anoxic ponds. Journal of Fish Biology 47:576-585.

Scott, W.B., and E.J. Crossman. 1973. Freshwater fishes of Canada. Fisheries Research Board of Canada Bulletin $184.966 \mathrm{pp}$.

Tuckett, Q.M., J.L. Ritch, K.M. Lawson, L.L. Lawson JR., AND J.E. HILL. 2016. Variation in cold tolerance in escaped and farmed nonnative green swordtails (Xiphophorus hellerii) revealed by laboratory trials and field introductions. Biological Invasions 18:45-56.

Walsh, J., D. Wuebbles, K. Hayhoe, J. Kossin, K. Kunkel, G. Stephens, P. Thorne, R. Vose, M. Wehner, and J. Willis, ET AL. 2014. Chapter 2: Our changing climate. Pages 19-67 in J.M. Melillo, T.C. Richmond, and G.W. Yohe, editors, Climate change impacts in the United States: The Third National Climate Assessment, U.S. Global Change Research Program.

[USDI] United States Department of the Interior, National Park Service, Grand Teton National Park \& John D. Rockefeller, Jr. Memorial ParkWAY. 2014. Resource report 2013, Moose, Wyoming, USA.

ZipPIN, C. 1958. The removal method of population estimation. Journal of Wildlife Management 22:82-90.

Received 3 February 2017 Accepted 17 August 2017 Published online 31 December 2017 